\title{
The influence of agricultural and industrial activities on the quality of water from public wells located in Ramnicu Valcea County \\ https://doi.org/10.21698/rjeec.2020.205 \\ Proceedings Paper
}

\section{CLAUDIU NARCIS SPINU, ILEANA CRINA NICOLESCU, CATALIN MANEA, MIHAIELA DRAGHICI}

National Research and Development Institute for Industrial Ecology - ECOIND, 182 Stirbei Voda, Ramnicu Valcea, 240588, Romania

Corresponding author (e-mail): claudiu.spinu@incdecoind.ro

\begin{abstract}
This study aimed to evaluate the quality of groundwater in an area with agricultural and industrial influences, located in Valcea County. Groundwater samples were collected in 2 campaigns from 14 public wells and were analyzed for $\mathrm{pH}$, conductivity (EC), arsenic $(\mathrm{As})$, cadmium $(\mathrm{Cd})$, chromium $(\mathrm{Cr})$, iron $(\mathrm{Fe})$, manganese $(\mathrm{Mn})$, nickel $(\mathrm{Ni})$, lead $(\mathrm{Pb})$, zinc $(\mathrm{Zn})$, copper $(\mathrm{Cu})$, nitrites $\left(\mathrm{NO}_{2}^{-}\right)$, nitrates $\left(\mathrm{NO}_{3}^{-}\right)$, ammonium $\left(\mathrm{NH}_{4}{ }^{+}\right)$and chlorides $(\mathrm{Cl})$. In most of the studied public wells, the laboratory results obtained for the physico-chemical parameters were within the limits imposed by the national legislation and those approved by the WHO. High levels of iron and manganese of natural origin were found at a public well located in a rural area and also chloride, at a well from the industrial area, which exceeds the imposed limits.
\end{abstract}

Keywords: groundwater, heavy metals, inorganic pollutants, public wells, water quality

\section{INTRODUCTION}

Widely used, groundwater is often the primary source of drinking water and contributes significantly to irrigation. It is generally recognized that in addition to the major elements such as calcium $(\mathrm{Ca})$, potassium $(\mathrm{K})$, magnesium, $(\mathrm{Mg})$, sodium $(\mathrm{Na})$, phosphorus $(\mathrm{P})$, and sulfur $(\mathrm{S})$, there are several elements including $\mathrm{Cr}, \mathrm{Cu}, \mathrm{Fe}, \mathrm{Mn}$, and $\mathrm{Zn}$ that are essential for many vital functions [1]. This valued resource can be severely affected by industrial and agricultural activities. Heavy metals are among the major contaminants of groundwater sources and their toxicity [2] depends on their concentration levels in the environment. A high concentration of heavy metals in the environment leads to a decreased retaining capacity of the soil causing groundwater pollution [3-6]. Nitrogen-based fertilizer applied on soil, industrial activities and landfill leachate can lead to groundwater pollution with nitrates, nitrites, and ammonia. In most soils, ammonium is rapidly converted to nitrate via nitrite by nitrification, where ammonium is oxidized to nitrite and then to nitrate through aerobic bacteria [7-9]. Natural levels of ammonia in groundwater are usually below $0.2 \mathrm{mg}$ of ammonia per liter. Higher natural contents (up to $3 \mathrm{mg} / \mathrm{L}$ ) are found in strata rich in humic substances or iron or forests [10]. Chloride in drinking water originates from natural sources, sewage and industrial effluents, urban runoff containing de-icing salt, and saline intrusion. Chloride concentrations around 250 $\mathrm{mg} / \mathrm{l}$ alter taste in water [11]. This study aims to evaluate the quality of groundwater used for drinking and irrigation, in terms of heavy metals and physical-chemical parameters specific to the activities carried out in the studied area. The samples were collected from 14 public fountains located in Valcea County, in areas with agricultural and industrial influences. Quality and chemical parameters analyzed (As, $\mathrm{Cd}, \mathrm{Cr}, \mathrm{Fe}, \mathrm{Mn}, \mathrm{Ni}, \mathrm{Pb}, \mathrm{Zn}, \mathrm{Cu}$, $\mathrm{pH}$, conductivity, $\mathrm{NO}_{2}^{-}, \mathrm{NO}_{3}^{-}, \mathrm{NH}_{4}^{+}, \mathrm{Cl}^{-}$) and the related laboratory results were compared with the national legislation (Law no. 458/2002 regarding the quality of drinking water) [12] and the values approved by World Health Organization (WHO) guidelines for drinking water. 


\section{EXPERIMENTAL PART}

Characterization of the studied area and location of the selected sampling points

Located in the central-southern part of Romania, Valcea County occupies $2-2.4 \%$ of the country's surface and covers $5.765 \mathrm{~km}^{2}$, of which $42.2 \%$ represents forests and $55 \%$ agricultural land. It is characterized by a moderate continental temperate climate, with slight Mediterranean influences in the hilly area. The mean annual rainfall is about 750 $\mathrm{mm}$. In terms of activities with possible effects on the environment, both industrial and agricultural ones characterize Valcea County. A large industrial platform located in the middle of the studied area is the place where several economic agents belonging to different industries (chemical, equipment for the petrochemical industry) operate. Besides, several factories belonging to the food and wood industries can be found in the area adjacent to Ramnicu Valcea (upstream of the industrial platform). Downstream of the industrial platform (P8-Babeni and P7Dragasani) activities belonging to extractive and vinification industries are carried out. To assess the water quality in public wells (powered by groundwater), 14 sampling points were selected to cover the influence of agricultural (P1 - P6, P7, P10, and P11) and industrial (P8, P9, P12, P13, and P14) activities on groundwater (Table 1, Fig. 1).

Table 1. Sampling points description

\begin{tabular}{|c|c|c|}
\hline $\begin{array}{c}\text { Sampling } \\
\text { point }\end{array}$ & $\begin{array}{l}\text { Location of the sampling point } \\
\text { (public wells) }\end{array}$ & Type of activity \\
\hline $\mathrm{P} 1$ & & \\
\hline $\begin{array}{l}\text { P2 } \\
\text { P3 } \\
\text { P4 } \\
\text { P5 } \\
\text { P6 }\end{array}$ & $\begin{array}{l}\text { Pesceana commune located west of River Olt, } \\
\text { composed of six villages (Cermegești, Lupoaia, } \\
\text { Negraia, Pesceana, Roesti, and Ursoaia), locations } \\
\text { where the public wells (sampling points) are located. }\end{array}$ & Agriculture \\
\hline P7 & Dragasani (downstream of the industrial platform) & $\begin{array}{c}\text { Agriculture } \\
\text { Wine industry }\end{array}$ \\
\hline P8 & Babeni (downstream of the industrial platform) & $\begin{array}{l}\text { Extractive industry } \\
\text { (Oil and gas) }\end{array}$ \\
\hline P9 & Ramnicu Valcea (upstream of the industrial platform) & $\begin{array}{l}\text { Food and Wood } \\
\text { Industry }\end{array}$ \\
\hline $\mathrm{P} 10$ & Budesti & Agriculture \\
\hline P11 & Pietrari & Agriculture \\
\hline $\begin{array}{l}\text { P12 } \\
\text { P13 } \\
\text { P14 }\end{array}$ & $\begin{array}{ll}\text { Copacelu } & \text { in the area adjacent to the industrial } \\
\text { Stolniceni } & \text { platform } \\
\text { Stuparei } & \end{array}$ & Industrial platform \\
\hline
\end{tabular}

\section{Sampling conditions}

The sampling campaign was performed from April to June 2020. Based on meteorological and hydrological data, these months have been characterized by drought. The water level in wells was about $15 \mathrm{~m}$. The wells were pumped out at least 15 min before the sample collection. Water sampling was performed following existing standards [13], as follows:

- from wells provided with a pumping system, the well water was pumped out at least 20 minutes before the sample collection,

- from wells provided with buckets, the samples were drawn up after emptying 4-5 buckets; the sampling was done from depths of $20-30 \mathrm{~cm}$ under the water mirror.

All samples were stored in polypropylene bottles at $4^{\circ} \mathrm{C}$ and analyzed within $24 \mathrm{~h}$, to minimize physical and chemical changes. 

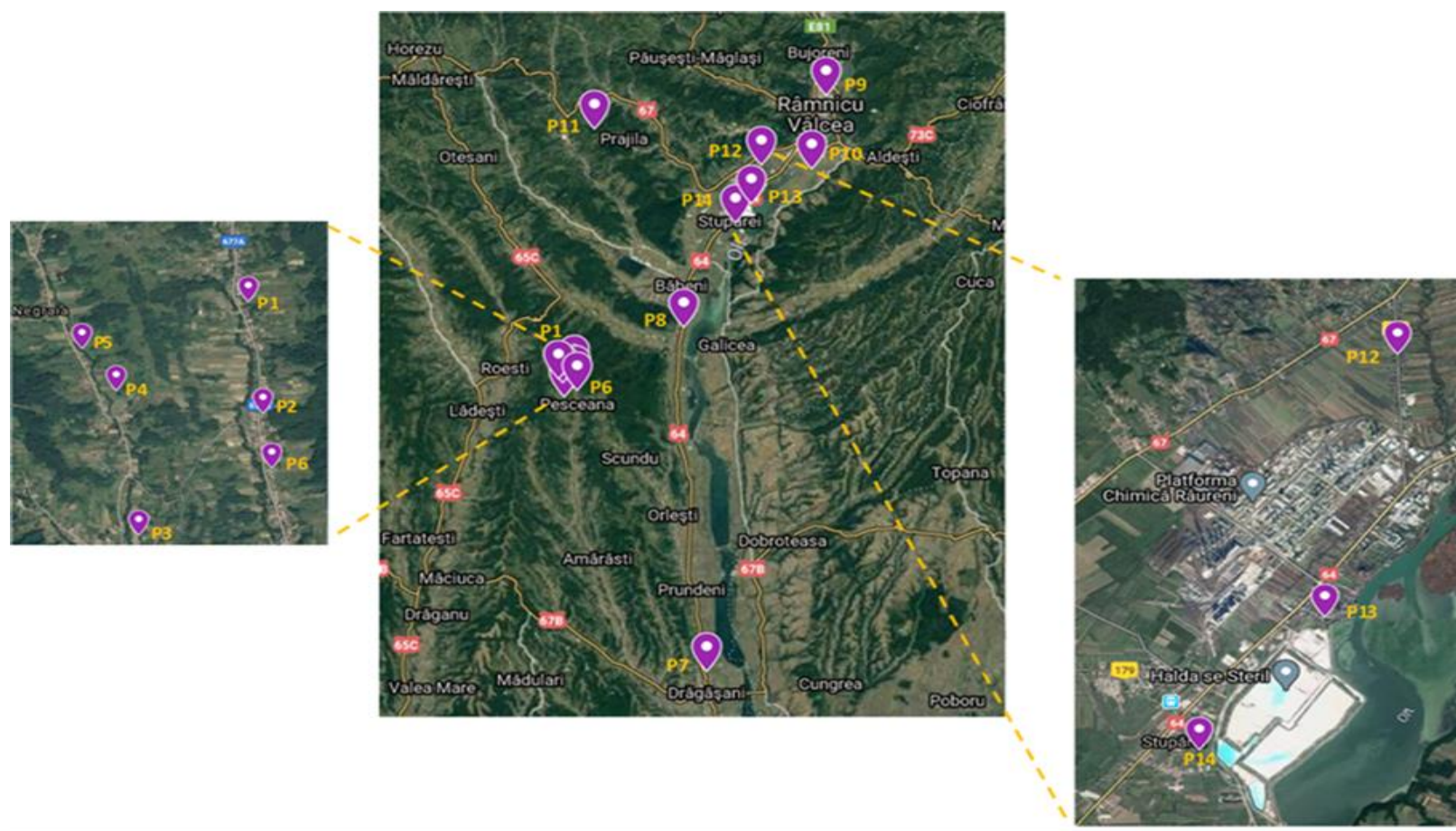

Fig. 1. Sampling points from Valcea County

\section{Chemical and physical analysis}

The determination of heavy metals in water was performed by induction coupled atomic emission spectroscopy (ICP-OES) according to SR EN ISO 11885:2009. The well water samples were filtered through $0.45 \mu \mathrm{m}$ filter paper. Subsequently, a known volume of each sample was digested with $2 \%$ ultrapure nitric acid solution and diluted to a final volume of 25 $\mathrm{mL}$ with the same acid solution. The solutions thus prepared, were analyzed for the simultaneous determination of $\mathrm{As}, \mathrm{Cd}, \mathrm{Cr}, \mathrm{Fe}$, $\mathrm{Mn}, \mathrm{Ni}, \mathrm{Pb}, \mathrm{Zn}$, and $\mathrm{Cu}$ contents, using an Optima 5300 DV Perkin Elmer Spectrometer. Inorganic parameters $\left(\mathrm{NO}_{2}^{-}, \mathrm{NO}_{3}{ }^{-}, \mathrm{NH}_{4}{ }^{+}\right)$were

\section{Quality control and assurance}

For the determination of metallic elements, sample preparation was carried out by digestion using trace select nitric acid $(69 \%$ Merck quality), diluted to a concentration of $2 \%$ with ultrapure water. CRM (100 mg/L Multi Element Standard Solution, Certipur, Merck) for metals and Certified Reference Materials traceable to

\section{RESULTS AND DISCUSSION}

Based on the laboratory results, statistical parameters (standard deviation "St $t_{\text {dev }}$ ", minimum "Min" and maximum "Max" of the values determined by spectrophotometric methods following the following standards: SR EN 26777:2002/ SR EN 26777:2002/ C91:2006 for nitrites, SR ISO 7890-3:2000 for nitrates, SR ISO 7150-1:2001 for ammonium. A Specord 210 Plus spectrophotometer was used for this purpose. To determine chloride content, the titration method was applied under SR ISO 9297:2001 standard. pH and conductivity values were recorded by using the multiparameter Thermo Scientific Orion Star A 215 following SR EN ISO 10523:2012 and SR EN 27888:1997 standards, respectively.

SRM from NIST for physical and inorganic parameters determination $(\mathrm{pH}$, conductivity, $\mathrm{NO}_{2}^{-}, \mathrm{NO}_{3}^{-}, \mathrm{NH}_{4}^{+}$, and $\mathrm{Cl}^{-}$) were used during the analysis, for purposes of quality control. All samples were analyzed in triplicate and the average was taken into consideration.

obtained, mean and median) were calculated. The results are centralized in Table 2 (statistical data) and highlighted in Figures 2-6. 
Table 2. The concentration of physical and chemical parameters of public wells in the studied area and some imposed limits

\begin{tabular}{|c|c|c|c|c|c|c|c|}
\hline $\begin{array}{c}\text { Parameter/ } \\
\text { measure unit }\end{array}$ & Mean & Median & $\mathrm{St}_{\mathrm{dev}}$ & Min & Max & *Law 458 & $* * \mathrm{WHO}$ \\
\hline $\mathrm{pH}$ & 7.29 & 7.30 & 0.23 & 6.90 & 7.4 & $6.5-9.5$ & $6.5-8.5$ \\
\hline $\begin{array}{c}\mathrm{EC} / \mu \mathrm{S} / \mathrm{cm} \\
\left(\text { at } 25^{\circ} \mathrm{C}\right)\end{array}$ & 897.7 & 841.5 & 351.0 & 385 & 1643 & 2500 & 800 \\
\hline As $/ \mu \mathrm{g} / \mathrm{L}$ & 2.59 & 2.45 & 1.96 & 0.60 & 8.20 & 10 & 10 \\
\hline $\mathrm{Cd} / \mu \mathrm{g} / \mathrm{L}$ & 0.41 & 0.40 & 0.04 & 0.40 & 0.60 & 5 & 3 \\
\hline $\mathrm{Cr} / \mu \mathrm{g} / \mathrm{L}$ & 1.41 & 1.30 & 0.53 & 1.30 & 4.10 & 50 & 50 \\
\hline $\mathrm{Fe} / \mu \mathrm{g} / \mathrm{L}$ & 79.2 & 33.5 & 139.5 & 12.1 & 567 & 200 & 300 \\
\hline $\mathrm{Mn} / \mu \mathrm{g} / \mathrm{L}$ & 10.8 & 3.60 & 21.3 & 1.60 & 93.7 & 50 & 50 \\
\hline $\mathrm{Ni} / \mu \mathrm{g} / \mathrm{L}$ & 1.31 & 1.20 & 0.32 & 1.20 & 2.80 & 20 & 20 \\
\hline $\mathrm{Pb} / \mu \mathrm{g} / \mathrm{L}$ & 0.51 & 0.18 & 0.50 & 0.15 & 1.90 & 10 & 10 \\
\hline $\mathrm{Zn} / \mu \mathrm{g} / \mathrm{L}$ & 23.9 & 7.10 & 45.0 & 3.90 & 184 & 5000 & 3000 \\
\hline $\mathrm{Cu} / \mu \mathrm{g} / \mathrm{L}$ & 5.67 & 2.90 & 6.88 & 2.10 & 33.3 & 100 & 200 \\
\hline $\mathrm{NO}_{2}^{-} / \mathrm{mg} / \mathrm{L}$ & 0.01 & 0.01 & 0.01 & 0.01 & 0.07 & 0.5 & 3 \\
\hline $\mathrm{NO}_{3}-\mathrm{mg} / \mathrm{L}$ & 9.85 & 5.80 & 12.1 & 0.09 & 37.5 & 50 & 50 \\
\hline $\mathrm{NH}_{4}^{+} / \mathrm{mg} / \mathrm{L}$ & 0.05 & 0.02 & 0.11 & 0.02 & 0.59 & 0.5 & - \\
\hline $\mathrm{Cl}^{-} / \mathrm{mg} / \mathrm{L}$ & 56.8 & 25.5 & 77.1 & 5.0 & 308 & 250 & 250 \\
\hline
\end{tabular}

*Law 458/2002 [12]; **WHO [11]

The $\mathrm{pH}$ values of all water samples ranged from 6.9 to 7.4 with an overall mean value of 7.29 that is very close to neutral. Electrical conductivity "EC" varies in range $(385-1643)$ $\mu \mathrm{S} / \mathrm{cm}$ at $25^{\circ} \mathrm{C}$, due to the presence of inorganic dissolved solids containing positive or negative

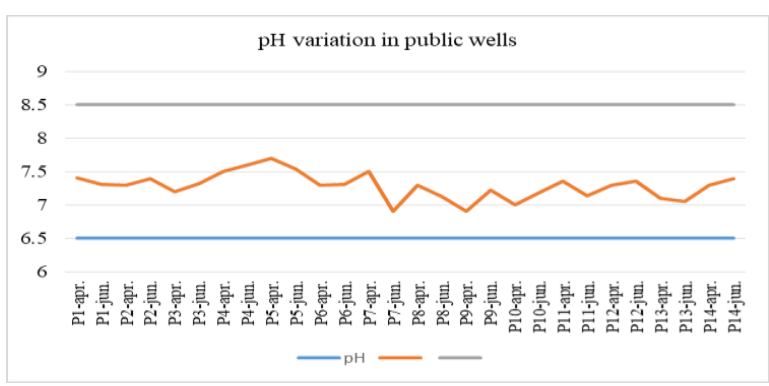

ions. All the registered values of $\mathrm{pH}$ and conductivity are below the limits set by the national legislation (Fig. 2). Compared with the values approved by WHO for conductivity, 8 public wells (P2, P3, P5, P7, P9, P11, P12, and $\mathrm{P} 14)$ exceed the maximum limits of $800 \mu \mathrm{S} / \mathrm{cm}$.

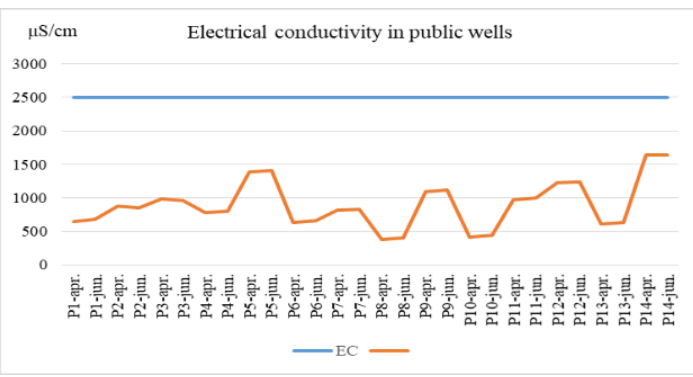

Fig. 2. Variation of the physical parameters ( $\mathrm{pH}$ and $\mathrm{EC}$ ) in public wells

Regarding heavy metals, the International Agency for Research on Cancer classifies arsenic, cadmium, lead, and nickel as group I carcinogens (Fig. 3). As seen in Table 2, the standard deviations are very small. The maximum of the laboratory results does not exceed the limits provided by current legislation or those approved by the WHO, for all studied wells. 


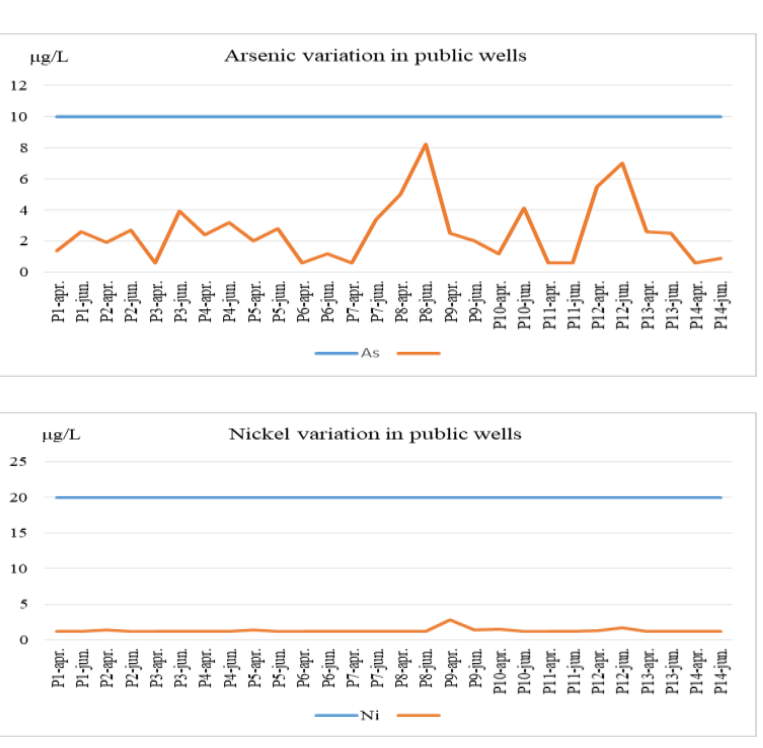

Fig. 3. Variation of $\mathrm{As}, \mathrm{Cd}, \mathrm{Pb}$ and $\mathrm{Ni}$ (group I carcinogens) in public wells

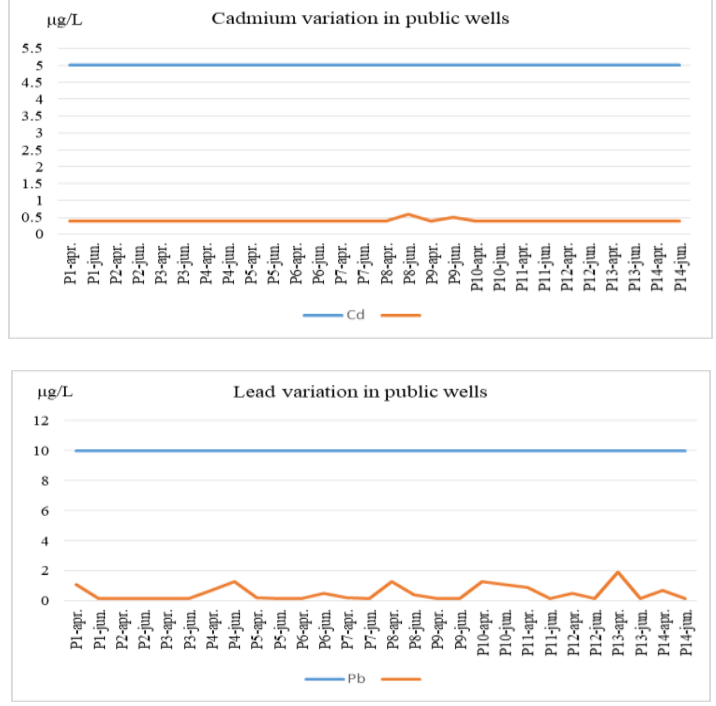

essential nutrient and a drinking-water contaminant. Some forms of copper or excess amounts can also cause health problems. The results obtained for total chromium and copper are well below the limit imposed by the national legislation (Fig. 4).

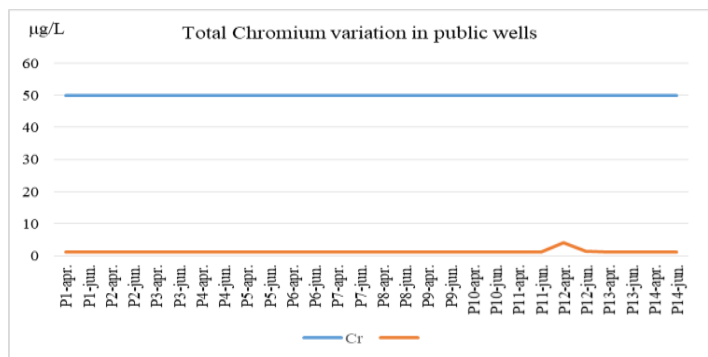

Fig. 4. Variation of $\mathrm{Cu}$ and $\mathrm{Cr}$ total in public wells

Following the literature data, natural sources of iron and manganese are more common in deeper wells, where the water has been in contact with rocks for a longer time. Both impart a strong metallic taste to the water and both cause staining. Iron and manganese are not hazardous to health. Instead, they both have secondary or recommended drinking water standards because they cause aesthetic problems and manganese is limited due to concerns about various neurological health effects [13]. The laboratory results for manganese and iron fall in a wide range of values (minimum and maximum values of $12.1 \mu \mathrm{g} / \mathrm{L}$ and $567 \mu \mathrm{g} / \mathrm{L}$ for iron and $1.60 \mu \mathrm{g} / \mathrm{L}$ and $93.7 \mu \mathrm{g} / \mathrm{L}$ for manganese). Accordingly, standard deviations are very high $(139 \mu \mathrm{g} / \mathrm{L}$ for iron and $21.3 \mu \mathrm{g} / \mathrm{L}$ for manganese). As seen in Figure 5, the high values of standard deviations are influenced by the concentrations of iron and manganese in water samples of the well - P11, these values exceeding approximately 2 times the limits imposed by the legislation. Taking into account the lack of industrial activities in the location area of the well - P 11 and following the literature data, the presence of manganese and iron in high concentrations is from natural sources. Like iron and manganese, zinc is not hazardous to health, but they are limited by both national legislation and the WHO. Most of the values obtained from laboratory analyses are at the limit of quantification of the method and consequently they are well below the allowed limits. 

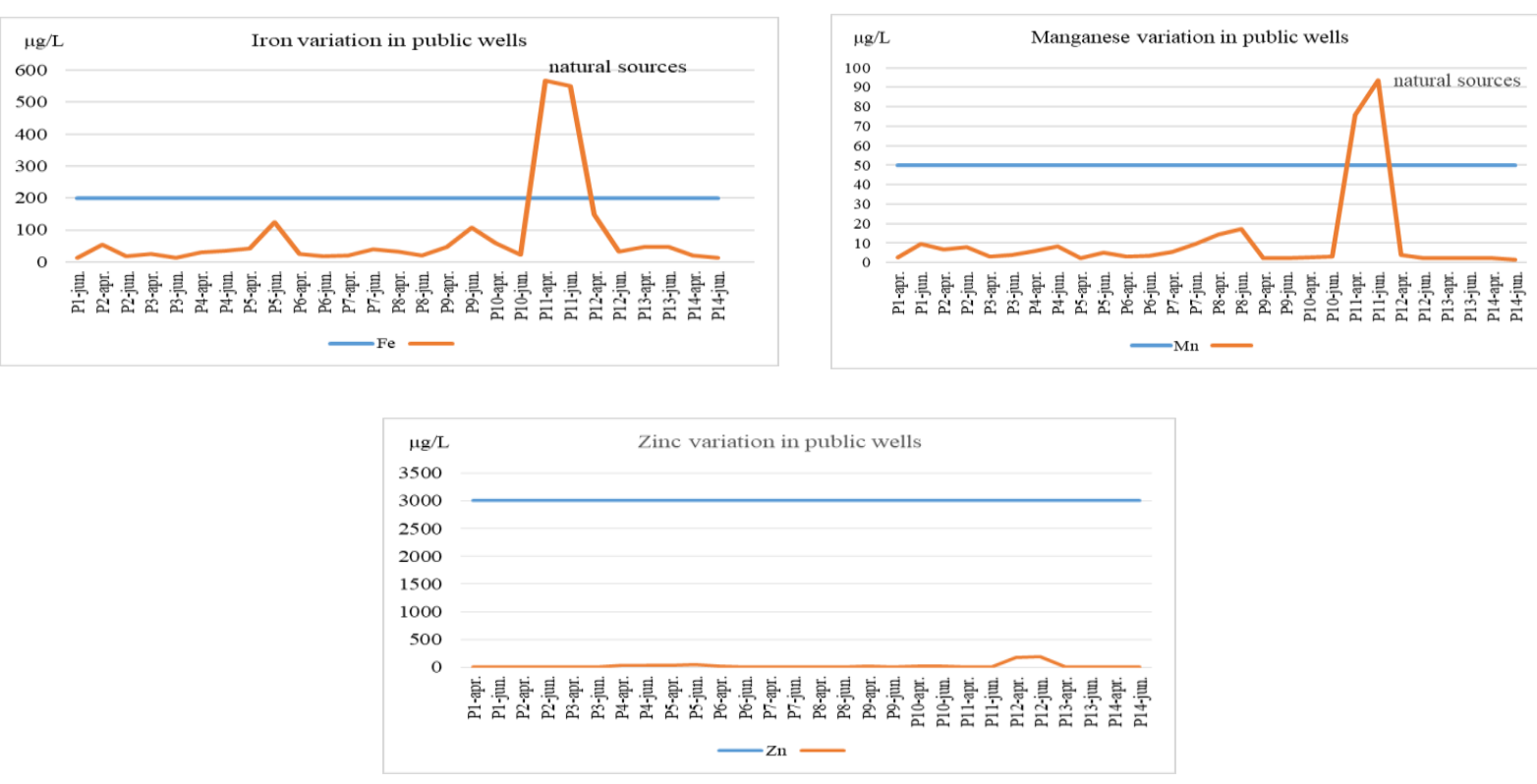

Fig. 5. Variation of the quality parameters $(\mathrm{Fe}, \mathrm{Mn}, \mathrm{Zn})$ in public wells

Regarding the inorganic chemical parameters: $\mathrm{NO}_{2}^{-}, \mathrm{NO}_{3}^{-}, \mathrm{NH}_{4}^{+}$, and $\mathrm{Cl}^{-}$, their levels in groundwater samples do not exceed the maximum allowed limits imposed by the legislation, excepting ammonium at P11Pietrari (influenced by agricultural activities) and chlorides at P14 - Stuparei (influenced by industrial activities) (Fig. 6). The presence of high levels of ammonium, manganese, and iron in well water at P11, and chlorides at P14, make the water of the public wells unusable for both drinking and agriculture, and consequently the water must be previously treated.
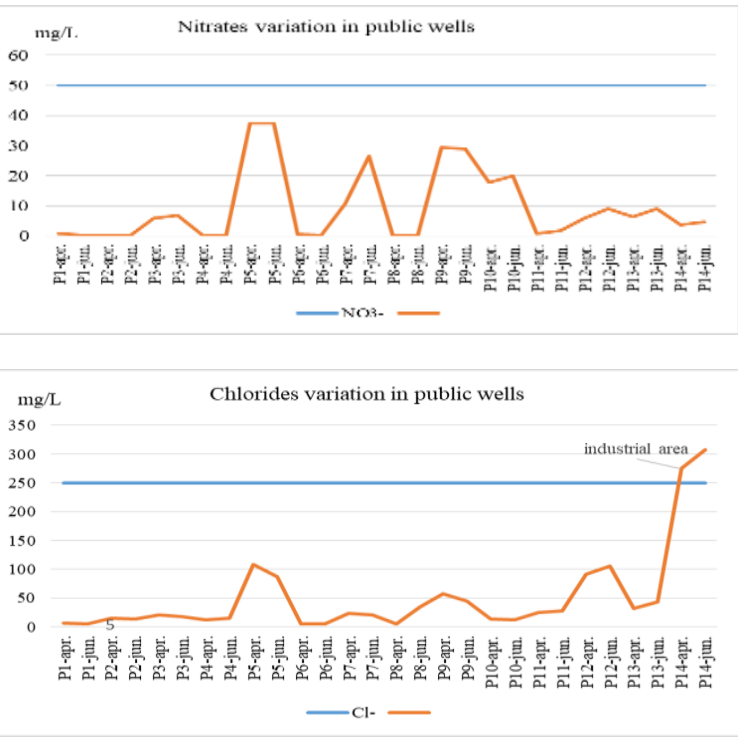

Fig. 6. Variation of $\mathrm{NO}_{2}^{-}, \mathrm{NO}_{3}^{-}, \mathrm{NH}_{4}^{+}$, and $\mathrm{Cl}^{-}$, in public wells

\section{CONCLUSIONS}

As the water from the studied public wells is a source of drinking water, it must meet the requirements imposed by the European legislation transposed into the national legislation for drinking water. In this paper, groundwater was studied as a source of supply for 14 public wells, these being located especially in rural areas adjacent to Valcea county, where industrial and agricultural activities take place. Most of the values 
recorded for physical parameters $(\mathrm{pH}$ and conductivity), heavy metals (As, $\mathrm{Cd}, \mathrm{Cr}, \mathrm{Fe}$, $\mathrm{Mn}, \mathrm{Ni}, \mathrm{Pb}, \mathrm{Zn}$, and $\mathrm{Cu}$ ), and inorganic parameters determined in the water samples taken from the studied public wells were within the limits imposed by the legislation in force and the limits approved by WHO. Exceptions are the levels of iron, manganese, and ammonium in the public well P-11 located near the forest, iron, and manganese being of natural origin. Taking into consideration the lack of industrial and agricultural activities in this location, ammonium might be present due to

\section{REFERENCES}

[1] IRITAS, S. B., TURKSOY, V. A., DENIZ, S., KOCOGLU, S., KIRAT, G., DEMIRKESEN, A. C., BABA, A., Water and Environ., 0, no. 1, 2018, p. 1, https://doi.org/10.1111/wej.12422.

[2] VAISHALY, A. G., BLESSY, B. M., KRISHNAMURTHY, N.B., Int. J. Adv. Sci. Res. Manag., 2, no. 1, 2015, p. 60.

[3] GHARAHI, N., ZAMANIAHMADMAHMOODI, R., Environ. Earth Sci., 79, no. 82, 2020, p. 79, https://doi.org/10.1007/s12665-020-8816-9. [4] STOICA, C., VASILE, G. G., BANCIU, A., NICULESCU, D., LUCACIU, I., NITALAZAR, M., Rev. Chim., 68, no. 8, 2017, p.1744.

[5] PAUN, I., CHIRIAC, F. L., PIRVU, F., VASILE, G., CRUCERU, L. V., MARIN, N. M., NICULESCU, M., VASILACHE, N., GALAON, T., Book of Abstract of the $21^{\text {st }}$ International Symposium on The Environmental and the Industry, Bucharest, Romania, 26-27 September 2019, p. 50, http://doi.org/10.21698/simi.2019.ab18.

[6] PRITI, S., BISWAJIT, P., J., Basic Appl. Eng. Res., 3, no. 8, 2016, p. 671.

[7] PRAKASA RAO, E. V. S., PUTTANNA, K., Curr. Sci., 79, no. 9, 2000, p. 1163.

[8] VASILE-SCAETEANU, G., MADJAR, R. M., PETICILA, G. A., Proceeding of the $21^{\text {st }}$ the high concentration of humus (due to the location near the forest) or iron ions. Another exception is the presence of chlorides in high concentrations at the public well $\mathrm{P}-14$, due to industrial activities in the area. The presence of these indicators in high concentrations at P-11 and $\mathrm{P}-14$ makes the water unusable, requiring a prior treatment. To protect the health of the communities, public wells must be constantly monitored, especially those wells that have values that exceed legal limits and if possible to be prohibited the consumption as drinking water.

International Symposium on The Environmental and the Industry, Bucharest, Romania, 26-27 September 2019, p. 337, http://doi.org/10.21698/simi.2019.fp43.

[9] CALIN, C., MADJAR, R. M., VASILESCAETEANU, G., OPRESCU, E. E., Book of Abstract of $3^{\text {rd }}$ International Colloquium Energy and Environmental Protection, Ploiesti, Romania, November 14th-16th, 2018.

[10] OSMANI M., HOXHA B., MALİ S., MAZRREKU A., KARAMELO P., GEGA N., BEKTESHI L., KARASALI V., KUCAJ E., BALLA J., Proceedings of International Conference on Veterinary, Agriculture and Life Science, Antalya, Turkey, 26 - 29 October 2019, p. 20., https://www.researchgate.net/publication/ 338936212.

[11] Guidelines for Drinking Water Quality, Fourth ed., World Health Organization, ISBN 978-92-4-154995-0.

[12] Law No. 458/2002. Drinking water, republished 2011, following Drinking Water Directive (Council Directive 98/83/EC of 3 November 1998 on the quality of water intended for human consumption).

[13] ISO 5667-11:2009. Water quality Sampling - Part 11: Guidance on sampling of groundwater. 